\title{
STUDENTS' COMMUNICATION STRATEGIES AND TEACHER'S RESPONSES IN A TWELFTH GRADE ENGLISH CLASSROOM IN PALANGKARAYA
}

\author{
Ribka Rayanti Juliany, Josefa Juniarti Mardijono \\ English Department, Faculty of Letters, Petra Christian University, Surabaya, East Java, Indonesia \\ e-mail: ribkarj@ymail.com, josefa@petra.ac.id
}

\begin{abstract}
This study is about communication strategies used by the students of twelfth grade and teacher's responses when they were having an integrated English class. The writer used Mariani's (2010) theory. The subjecs of the study were 19 students and 1 teacher. The source of data was the students' and teacher's utterances during the two meetings. The data were the students' and teacher's utterances, (verbal and non-verbal (gestures, eye contact, facial expressions)) which contain communication strategies related to the topic learning. The findings of this study revealed that students used four types of Communication Strategies: Meaning-expression, Meaning-negotiation, Conversation-management and Para- and extra linguistic. The students used these strategies mostly because they were unsure how to answer the teacher's question and did not know the meaning of the word. The writer hopes that there would be a further study which focused about conversation or speaking class.
\end{abstract}

Key words: Communication Strategies, Teacher's Responses

\section{INTRODUCTION}

Communication is taking an important part of human daily life. It is a tool to express what the speakers want to say or feel to another speaker. In the classroom, communication between teacher and students is important. By having communication with the teacher, the students can get the information about the lesson that is being taught by the teacher. Meanwhile, the teacher can know the students' problems in learning and teaching process.

In Indonesia, English is learned as a foreign language (EFL) and becomes one of the compulsory subjects in Indonesian curriculum (Mappiase and Sihes, 2014). English is not Indonesian students first language, therefore they might have problems to communicate in the target language. It also can happen when the students have to interact using English with their teacher in the classroom.

According to Mariani (2010), the major problems of foreign and second language learners are coming from three aspects: linguistic, cultural, and contextual aspects. The writer focuses on the linguistic aspects because the subject for this study is more into language output from the lesson in the classroom situation. One of the examples from linguistic aspect is the "lacking of knowledge of the language"(Mariani, 2010, p. 7). Lacking or limited knowledge of the language can make the students difficult to express the messages or ideas in their conversation. It shows that using English to communicate is not easy if the speaker's L1 (first language) is not English.

To overcome the problems, it is necessary for the learners to find efficient means through which they can convey their ideas" (Hua et al., 2012). To convey ideas and messages, clear and precise communication strategies are needed. Communication strategies are related to the way both speaker and interlocutor maintain and sustain communication. According to Tarone (1979), as cited in Mariani (2010), states that communication strategy is "a mutual attempt of two interlocutors to agree on a meaning in situation where requisite meaning structures do not seem to be shared. (Meaning structures include both linguistic and sociolinguistic structures)." In addition to Tarone's definition, Mariani (2010) states that communication strategies are the ways of reaching goals in communicating when interlocutors encounter an issue in communication, like unable to understand what is being talked (Mariani, 2010). It means that the interlocutors can try to keep the conversation open by using communication strategies which are important in classroom interaction. In other words, communication strategies can help the speakers to express ideas or messages between speakers and listeners. 
In order to analyze the communication strategies, the writer used the theory from Mariani (2010). Mariani classifies communication strategies into one typology that consists of five groups: meaning-expression strategies, meaning-negotiation strategies, conversation-management strategies, para- and extra linguistic strategies and (intercultural) interaction-monitoring strategies. The writer used this theory to analyze the utterances produced by the students. Then, the writer recorded the interaction when the students were having an integrated English class in the classroom. The classroom interaction involves communication between students and teacher which is the situation needed to be analyzed by the writer using communication strategies theory. In addition, English subject in this high school was an integrated subject which consists of speaking, writing, listening, and reading. The school itself did not have specific classes for English subjectc like only conversation or spoken classes. So, the writer chose this English subject to be analyzed.

The writer also analyzed the teacher's responses toward students' communication strategies in the classroom. The teacher is Ms. Riana Asihai. She graduated from the undergraduate program of the Faculty of Teacher Training and Education at Palangkaraya University in Palangkaraya. She had been teaching in this school for 13 years. At present, she teaches seven classes of twelve grade in this school including the language program class which is the observed class.

For collecting the data, the writer did the recording in the classroom for two meetings. The writer used the video recording and audio recording. The video recording used to record the extralinguistic signals (non-verbal language) of the students and teacher, such as gestures, eye contact and facial expressions in the classroom. The audio recording was used to record the utterances that were produced by the students and teacher when they were having an integrated English class. These steps were done to analyze and answer the research questions which were the types of classroom communication strategies used by the students to their teacher and the teacher's responses.

\section{METHODS}

In this study, the writer used a qualitative approach (Cresswell, 2013). The writer was the instrument who collected the data and analyzed the data based on the theories in chapter two. The focus of the study was communication strategies based on Mariani (2010). The source of data was the students' and teacher's utterances during the integrated English class. The data were the students' and teacher's utterances (verbal and non-verbal (gestures, eye contact, facial expressions)) which contain communication strategies related to the learning topic. The conversation was recorded using audio and video recording. The video recording was used to record the extra-linguistic signals (nonverbal language) of the students and teacher, such as gestures, eye contact and facial expressions in the classroom. The audio was recording used to record the utterances that were produced by the students and teacher during the class.

After doing the recording, the writer transcribed the audio recording and saw the video recording to complete the source of data. The order of classroom recordings and transcription processes were described using Walsh (2011) transcription system. The writer recorded the first meeting and transcribed it. Then, the writer repeated the same process for the second meeting.

In analyzing the data, the writer applied three digits numbering. The first digit refer to the meeting, which meant "1" for the first meeting, and "2" for the second meeting. The second digit refers to the person like: $1=$ teacher, $2=$ all students , $3=$ individual student. The third digit refers to the order of teacher's and students' dialogue line in a meeting.

For the transcription of the audio recording, the writer used transcription system developed by van Lier (1998) and Johnson (1995), cited in Walsh (2011). The writer used this system to support her study by giving details in her transcripts. The transcription system is described as the following:
T: $\quad-$ teacher
L: $\quad$ - learner (not identified)
L1, L2, etc.: $\quad$ - identified learner
LL: $\quad$ - several learners at once or the whole class
[do you understand?]
[I see] - overlap between teacher and learner
$=\quad-$ turn continues, or one turn follows another without any pause
(4) - silence; length given in seconds
? $\quad$ - rising intonation - question or other
! - emphatic speech: falling intonation 
((4)) - unintelligible 4 seconds a stretch of unintelligible speech with the length given in seconds

Paul, Peter, Mary - capitals are only used for proper nouns

T organises groups - editor's comments (in bold type)

(Walsh, 2011, p.126)

The analysis of this study is based on the theory in chapter two. With the purpose of answering the research questions of this study, the table below was used.

Table 1.1 Table for Analysis of Communication Strategies

\begin{tabular}{|l|l|l|l|l|l|}
\hline \multirow{2}{*}{ No. } & Utterances & \multirow{2}{*}{$\begin{array}{c}\text { Communication } \\
\text { Strategies }\end{array}$} & \multicolumn{2}{|c|}{$\begin{array}{c}\text { Teacher's } \\
\text { Response }\end{array}$} & \multirow{2}{*}{ Notes } \\
\cline { 4 - 5 } & & & $(+)$ & $(-)$ & \\
\hline & & & & & \\
\hline & & & & & \\
\hline & & & & & \\
\hline
\end{tabular}

Note:

Communication Strategies:

PW : Purpose Word

GW : General Word

SA : Synonym or Antonym

E : Examples

DD : Definitions or Descripions

AP : Appromaximations

PR : Paraphrasing

SC : Self Correcting

AFH : Asking for Help

GV : Giving Help

$\mathrm{OC}$ : Opening and Closing

KCO : Keeping Conversation Open

MTT : Managing Turn Taking

ACT : Avoding or Changing Topic

GT : Gaining Time

UIP : Using Intonation Patterns

NV : Non Verbal

AI : Asking Interlocutors

NW : Noticing Words

CR : Checking Reactions

COI : Cheking One's Interpretation

A : Apologizing

DWU : Dealing With Uncertainty

The "Utterances" column was used to write the transcription for the two meetings. The writer used the transcription system which is developed by van Lier (1998) and Johnson (1995), cited in Walsh (2011) as explained on page 23. From the transcription, the writer was able to see and differentiate which one that belongs to several strategies. Then, the "notes" column was used to give explanation about the use of several communication strategies and the teacher's responses during the lesson.

\section{ANALYSIS AND FINDINGS \\ Table 1.2 The Types of Communication Strategies used by the Students and the Teacher's Responses}




\begin{tabular}{|c|c|c|c|c|}
\hline \multirow{2}{*}{$\begin{array}{c}\text { Strategies } \\
\text { Teacher's Responses of Communication }\end{array}$} & $\begin{array}{c}\text { Meaning- } \\
\text { expression }\end{array}$ & $\begin{array}{c}\text { Meaning- } \\
\text { negotiation }\end{array}$ & $\begin{array}{c}\text { Conversation- } \\
\text { management }\end{array}$ & $\begin{array}{c}\text { Para- and } \\
\text { extra } \\
\text { lingustic }\end{array}$ \\
\cline { 2 - 5 } & SC & AFH & UT & UNVL \\
\hline$(+)$ & $\sqrt{ }$ & $\sqrt{ }$ & $\sqrt{ }$ & $\sqrt{ }$ \\
\hline$(-)$ & & & & \\
\hline
\end{tabular}

Notes:

SC : Self-Correcting

AFH : Asking For Help

UT : Using Tactics

UNVL : Using Non-Verbal Language

From the table above, it can be seen that the students used four types of communication strategies: meaning-expression, meaning-negotiation, conversation-management and para- extra linguistic strategies when students are talking to the teacher. It is also shown that most of the responses from the teacher are positives and there is no negative responses from the two meetings observed. The further explanations are described below.

\subsubsection{Meaning-expression Strategies}

Meaning-expression strategies was used "to express a meaning when the spesific expression is not (yet) available to the speaker" (Mariani, 2010, p.32). In this study, it occurs when the student tried to correct himself when he spotted misunderstanding. The student realized the mistake after the teacher repeated his answer.

\subsubsection{Self-Correcting, Rephrasing, Repairing Incorrect or Inappropriate Utterances or When Spotting A Misunderstanding}

This is the example when the student used self-correcting when he was talking to the teacher.

$\mathrm{T} \quad$ : feel hungry but feel angry?

L $\quad$ : no-no bu eh salah (1.3.12) (page 69)

(no-no bu, eh I was wrong)

From the example above, the student was trying to answer the teacher's question. It can be seen from the previous utterances, the student made a mistake by saying "angry" instead of "hungry". The teacher tried to give a hint that the answer was wrong. The teacher asked the student by repeating and asking for confirmation about what the student has been said, "feel hungry but feel angry?". After that, the student realized the answer was not "angry" but "hungry" and he corrected himself after spotting misunderstanding. Thus, the student said, "no-no bu eh salah". In this data, the student corrected himself after the teacher gave a hint for him by repeating his answer. He corrected by saying," no-no bu eh salah" but he did not give the answer. After the student got the hint, he was able to know the correct answer from the teacher in a implicit way. Furthermore, the utterance "nono bu eh salah" is categorized as self-correcting when spotting misunderstanding because when the student realized the mistake, he tried to correct himself even though he did not say the answer.

\subsection{The Teacher's Response}

The teacher gives positive responses toward the students' communication strategies which is meaning-expression in the form of self-correcting, rephrasing, repairing incorrect or inappropiate utterances or when spotting a misunderstanding. The example is presented below.

$\mathrm{T} \quad$ : oh ya silahkan ditulis dulu (5) (oh yes you can write it first) wah masih banyak ni (2) (wah there still much left) I will give you two crackers (4) supaya you're not feel hungry (so you're not feel hungry)

L : : yes (laughs) I am-I am still-still angry

$\mathrm{T} \quad$ : feel hungry but feel angry?

LL : (laughs)

L $\quad$ : no-no bu eh salah (no-no bu, eh I was wrong)

$\mathrm{T} \quad$ : I feel angry (low voice) (T makes a joke) (1.1.13) (page 69)

LL : (laughs) 
From the example above, the student made a mistake by saying "angry" instead of "hungry". The teacher asked him again to check his understanding from the student's answer. From the utterances, the other students were laughing because one of their friends was making a mistake. After the student corrected himself, the teacher's response was "I feel angry". It seemed that the teacher was angry when she responded to the student, but she was actually just throwing a joke. It can be seen from the utterance, she actually said the line with low voice. Also, in the next utterance all the students were laughing because they knew the teacher just made a joke and was not angry. From these utterances, the teacher did not explicitly say that the answer was wrong to the student. The student was able to know the answer when the teacher gave a hint by asking for confirmation. The teacher just asked for confirmation and even made a joke. The writer assumed that the teacher did not give negative response because she wanted to the student to be brave to talk in English even though it was not the correct word/sentence. By making a joke, the student would not feel afraid to make mistakes. Meanwhile, if the teacher was mad or ignored the mistake at the student, they would not say anything in class because they were afraid. Th students also did not know that he/she made mistake. Futhermore, the utterance "I feel angry" is categorized as positive responses because the teacher did not directly get at the student when he made a mistake.

\subsubsection{Meaning-negotiation Strategies}

Meaning-negotiation strategies is "used to develop meaning in the interaction from both interlocutors" (Mariani, 2010). The students used meaning-negotiation strategies when they were facing difficulty in understanding the meaning of a word. Then, they asked a help from the teacher.

\subsubsection{Asking For Help}

Asking for help is one of the strategies to help the speaker get the answer from another speaker. The examples of asking for help are telling that she/he cannot say or understand something (directly \& indirectly), asking to repeat, or guessing meaning and asking for confirmation. These are the examples when the student used meaning-negotiation strategies in the form of asking for help that appeared in the class.

$\mathrm{T} \quad$ : the common one?

L : hah? common-common.. emm apa bu? (1.3.3) (page 64)

(what do you mean, ma'am?)

From the example above, the first utterance the teacher asked the student was, "the common one?". From the previous utterances, the teacher asked the students what was the English word for "ibu" and the students answer was "mom", "mother" and "mommy". The teacher's purpose of asking was to get the expected answer which was "mother". However, one student seemed not understand the meaning of the word. It can be seen from the second utterance, the student repeated the word "common" for two times and asked the teacher what the meaning was to get the answer. Thus, the utterance "hah? common-common.. emm apa bu?" is categorized as asking for help which the student asked a help from the teacher to get the answer.

\subsection{Teacher's Response}

The teacher gives positive response toward the students' communication stategies which was asking for help. The positive response means that the teacher helped to answer the student's question to the teacher. The example is presented below.

L : maksudnya bu? narai bu?

(ma'am, what do you mean?)

$\mathrm{T} \quad$ : yang umum yang umum (2) mooo? (1.1.2) (page 65)

(the common one the common one (2) mooo?

L : : ther...

From the example above, the student asked the teacher what was the teacher's question. The student said "maksudnya bu?" in Bahasa Indonesia or "what do you mean, ma'am?" and added with their dialect (Dayak): "narai" which meant "what". From the utterances, it can be seen that the student actually has asked the teacher using Bahasa Indonesia. However, the student added the dialect. The writer assumed this was a strategy to show and emphasize that the student did not really understand the meaning and asked twice. The second utterance showed that the teacher directly answered the student's question and also gave a hint. The teacher gave the expected answer in 
Bahasa Indonesia. As a result, the student was able to answer the question. Thus, the utterance "yang umum yang umum (2) mooo?" is categorized as a positive response.

\subsubsection{Conversation-management Strategies}

The third strategy is conversation-management strategies. This strategy is one of the ways to "handle some particulary difficult aspects of conversation". The writer found that the students used conversation-management strategies in a form of using tactics to gain time.

\subsubsection{Using Tactics to "Gain Time" and Keep The Conversation Channel Open}

These strategies are using tactics to "gain time" and keep the conversation channel open. There are six sub verbal strategies included which are using pauses/remaining silent, umming/erring/mumbling, using filler/chunks, waffling, repeating oneself and repeating one's interlocutor words. The example of the strategy used by the students is presented below.

$\mathrm{T} \quad$ : ada subject plus have or has plus verb three (2) (there is subject plus have or has plus verb three) disini Jeki (2) (Jeki is here) to be nya? pakai have apa has? what is the to be? ayo I have told you (2) (what is the to be? use have or has? what is the to be? c'mon I have told you) ayo in English (c'mon in English)

$\mathrm{L} \quad$ : the to be is is emm is pakai (the to be is is emm is use) (1.3.10) (page 69)

From the example above, the teacher asked the student what was the right form of to be for the subject that had been given. Then, the student tried to answer the question but he was not sure with his answer. It can be seen from the utterance, "the to be is is emm is pakai" he used umming to express that he tried to answer. Furthermore, the utterance "the to be is is emm is pakai" is categorized as using tactics in a form of umming.

\subsection{Teacher's Responses}

The teacher gave positive response toward the student's communication strategies in a form of using tactics. The positive response here means the teacher gave a hint to the students by asking question to emphasize the answer of the teacher's question. The example is presented below.

$\mathrm{L} \quad$ : the to be is is emm is pakai (the to be is is emm is use)

$\mathrm{T} \quad$ : pakai? (1) pakai? (using (1) using?) (1.1.11) (page 69)

L : has-has

L : verb three

T : verb three nya apa? (2) dari writing dirubah ke verb three jadi?

From the example above, the student tried to answer the question from the teacher. Then, from the second utterance, the teacher asked the student and said : "pakai? pakai?" which wanted to give emphasis that the student should give the answer. The teacher encouraged the student to be able to answer the question. From the previous utterances, the other students tried to answer but they were not really sure. Then, the other students tried to answer and that was correct. The teacher did not say that was the right answer (explicitly) but she went straight to the next. The result was the teacher got the answer from another student. Furthermore, the utterance "pakai? (1) pakai? (using (1) using?)" considered as positive response because the teacher gave the hint for the students.

\subsubsection{Para- and extra linguistic Strategies}

The students used para- and extra-linguistic strategies to answer teacher's question by doing non-verbal response.

\subsubsection{Using Non Verbal Language}

The example of using non-verbal language is below.

$\mathrm{T} \quad$ : object tu nah Min limbah kata jituh Min berarti narai limbah kata jituh? (The object is after this word Min, so what is the next word after this?)

L : (looks at the board) (makes eye contact to $\mathrm{T}$ ) (2.3.3) (page 75)

From the example above, the teacher asked the student in front of the class. From the second utterance, the student just looking at the board and making eye contact to the teacher instead of asking the teacher if he did not understand. Furthermore, the non-verbal response "(looks at the board) (makes eye contact to T)" is categorized as using non-verbal language. 


\subsection{Teacher's Response}

The teacher gave positive response toward the student's communication strategies in a form of using non-verbal language. The positive response here means the teacher gave a hint to the students by asking question to emphasize the answer of the teacher's question. The example is presented below.

L : (looks at the board) (makes eye contact to $\mathrm{T})$

$\mathrm{T} \quad$ : ela kau payah aku (4) (don't look at me) di atas itu berarti apa? (1) dari sini (1) apa ini? (3) keterangan? (10) (so what is the word up there? (1) from here (1) what is this? (3) adverb of? (10)) (2.1.3) (page 75)

From the example above, the teacher's response toward the student was giving a comment which was: "don't look at me" and also gave a hint. Even though she told the student not to look at her, she also gave a hint in order to make the student understand and get the hint. She wanted the student to think more to get the answer. So, this is considered as a positive response.

\section{CONCLUSION}

Based on the writer's findings, the writer found that the students used four types of communication strategies: meaning-expression, meaning-negotiation, conversation-management and para- and extra linguistic. The students did not use all sub-strategies included in each type of communication strategies. The students only used self-correcting, asking for help, using tactics and using non-verbal language. The data were collected when the students learned passive sentence in the classroom. The students used these strategies mostly because they were unsure to answer the teacher's question and did not know the meaning of the English words.

The writer tried to analyze the teacher's responses. The result showed that the responses from the teacher were positives and there was no negative response toward the students. The teacher gave positive responses in order to make the students understand the lesson. From the utterances, the teacher tried to encourage the students to be able to answer by repeating her explanation, asking more questions and showing the previous examples to them. As a result, the students were able to get the answer from the teacher's help by giving the responses.

The writer hopes that there would be a further study which focuses on conversation or speaking class. The conversation or speaking class requires the students to extensively talk in English that it will yield richer data. Another suggestion is to conduct a further study on small classes to get clearer and richer data.

\section{REFERENCES}

Cresswell, J. (2013). Designing a qualitative study: Choosing among five approaches (4th ed.). Los Angeles: SAGE.

Hua, T.K., Nor, N.F.M., \& Jaradat, M.F. (2012). Communication Strategies Among EFL Students An Examination Of Frequency Of Use And Types Of Strategies Used. Journal of Language Studies, 12(3), 831-848.

Mappiase, S.S and Sihes, A. J. B. (2014). Evaluation of English as a Foreign Language and Its Curriculum in Indonesia: A Review. English Language Teaching. 7(10), 113-122.

Mariani, L. (2010). Communication Strategies. Learning and teaching how to manage oral interaction. Milan: Learning Paths - Tante Vie Per Imparare.

Walsh. S. (2011). Exploring classroom discourse. Language in action. New York: Routledge. 